J. Dairy Sci. 104:8340-8340

https://doi.org/10.3168/jds.2021-104-7-8340

() 2021 American Dairy Science Association ${ }^{\circledR}$. Published by Elsevier Inc. and Fass Inc. All rights reserved.

\title{
Corrigendum to "Lactational response of early-lactation Holstein cows fed starch or floury corn silage" (J. Dairy Sci. 103:5118-5130)
}

\section{Ishwary P. Acharya and David P. Casper}

In this paper, the term "leafy-floury silage" was used to describe the corn silage hybrids evaluated in the study. However, the hybrids studied did not contain the leafy gene nor did they contain a gene (floury gene, the opaque- 1 gene, or the opaque-2 gene) that would result in kernels containing mostly floury endosperm. The hybrids studied were conventional standard/yellow dent corn varieties. The terms "starch" and "floury corn silage" were used as common industry terms to define the differences in ruminal starch digestion that were observed with the different corn silage hybrids evaluated in this study. However, the use of a standard industry term "floury" was not intended to indicate the floury gene, the opaque-1 gene, or the opaque-2 gene. Our intention was to characterize the corn starch structure using a common industry term that would be readily understood by the reader.

The running header "STARCH OR LEAFY-FLOURY CORN SILAGE FOR COWS" should read "STARCH OR CORN SILAGE FOR COWS".

The first sentence of the Acknowledgments was incorrect and should read: "The authors thank Masters Choice (Anna, IL) for the donation of corn seeds."

The authors regret the errors.

\section{REFERENCES}

Acharya, I. P., and D. P. Casper. 2020. Lactational response of early-lactation Holstein cows fed starch or floury corn silage. J. Dairy Sci. 103(6):5118-5130. https://doi.org/10.3168/jds.2019-16767. 